\title{
Review of Iara Vigo de Lima's Foucault's archaeology of political economy. New York (NY): Palgrave Macmillan, 2010, 274pp.
}

\author{
RYAN WALTER \\ Australian National University
}

Vigo de Lima has set herself the difficult task of selling Michel Foucault to historians and methodologists of economic thought. Foucault's name is closely associated with the 'theory boom' of the 1960s and 1970s, which is enough to arouse the suspicion of most economists. A second marketing challenge is to overcome the effrontery embodied in Foucault's decision to write histories of extremely varied terrains, including medicine, grammar, classical sexual ethics, and political thought. Worse, all of Foucault's histories offer powerfully revisionist narratives, but seemingly from the perspective of an outsider sticking his nose into another discipline's past. A final issue for the Foucault salesperson is that, except for the final two volumes of The history of sexuality, the narratives of all of his book length histories are driven by philosophical schemas that can both alienate readers and compromise the empirical credentials of his conclusions. What is Vigo de Lima's sales strategy? It is to pitch to a small minority who are prepared to buy highgrade Foucault, and this is both a strength and a weakness of the book.

To understand why the book's strategy should be seen in these terms, the first point to note is which part of Foucault's work Vigo de Lima has studied. As her title indicates, it is the archaeological phase, or the 'early Foucault'. Three monographs originally published in the sixties are typically assigned to this stage (History of madness, birth of the clinic, and The order of things), along with an unwieldy methodological treatise (The archaeology of knowledge). This instruction manual effaced most of the methodological diversity of the earlier studies to present a codified method complete with specialised terminology, neither of which Foucault would ever use, since he promptly shifted method and commenced his 'genealogies' or 'middle period'. Yet this method text-obsolete by the 1970s-is worked through patiently by Vigo de Lima, taking the reader through the ostensibly oxymoronic labels, such as 'historical a priori' and 'system 
of dispersion'. The other text central to this study is The order of things, where Foucault's principal engagement with the history of economic thought is found.

From the marketing perspective, the trouble here is that The order of things is Foucault's most inaccessible text and the most historically unsound. Foucault asserted the existence of an episteme, a matrix existing beneath concrete forms of knowledge that structures the form these surface knowledges can take. On this basis, shifts in the underlying episteme will be reflected in shifts in its surface manifestations, and Foucault described two such shifts-from the Renaissance to the classical, and from the classical to the modern. This is sweeping enough, but Foucault's case studies were three distinct disciplines: grammar, biology, and economics. The resulting scale of The order of things is what makes it so breathtaking to read and yet so empirically flawed, as specialists from the relevant fields have noted. These concerns are acknowledged occasionally but they are not seriously confronted (see pp. 36, 57, 150, 209, 211, 214-215, 225, 243244). Vigo de Lima's primary tactic is instead to repeat what Foucault said in The order of things and then suggest that his account is broadly supported by mainstream historians of economic thought, particularly Mark Blaug and Joseph Schumpeter (for example, pp. 195-196). This approach may not persuade the majority.

An alternative path for linking Foucault with the history of economic thought is to centre his studies of 'governmentalities' - the rationalities that inform particular practices of government. One might think here of the way a discourse of sovereignty is invoked to justify acts of war, while tax cuts tend to be discussed using economic language; war and taxation are particular practices of government and they correspond with distinct bodies of knowledge. There is now a sizeable literature examining this aspect of Foucault's thought, which derives primarily from his lectures at the Collège de France, circa 1977-1979 (Foucault 2007; 2008). The Anglophone reception of this research program was greatly spurred by the publication of The Foucault effect (Burchell, et al. 1991), and aided by a rich vein of work centred on the journal Economy and Society. Much of this literature is synthesised by two invaluable survey works-Mitchell Dean's Governmentality (1999), and Nikolas Rose's Powers of freedom (1999). This relevant literature is missing from Vigo de Lima's book, and this is a shame, for the distinguishing mark of 
the governmentality material is that it builds on Foucault's insights and often subjects them to severe revision.

This last point leads to the second reason to question Vigo de Lima's marketing vision. The balance between, on the one hand, recapitulating what Foucault had to say about method and the history of economics and, on the other hand, picking up some of his pointers to develop a new historical narrative is overwhelmingly weighted in favour of recapitulation. Of the five substantive chapters, only chapters 5 and 6 relate to the history of economic thought, while the other three develop a reading of Foucault's archaeology. Chapter 5 takes the reader through Foucault's account of how mercantilism and physiocracy belonged to the classical episteme, analysing the representation of wealth in relation to the circulation of bullion and goods in the body politic. We are told that Foucault portrays Smith as partially escaping this epistemological epoch by examining the role of labour in creating wealth, but that ultimately Smith remains tethered to classical thought by his treatment of exchange. To understand this part of Foucault's argument it is necessary to know that he treats Ricardo and Marx as ushering in political economy, in which the finitude of man as a being that must labour for his survival is the central analytical figure, replacing the circulation of wealth (the key theme for earlier classical thought). Smith is therefore a transition figure in this aspect of Foucault's work, having one foot in each camp.

Yet in his later work on governmentality Foucault makes Smith emblematic of a shift to classical liberalism and the rejection of sovereign-centred conceptions of government, such as mercantilism. The point to note here is that Foucault's reading of Smith is largely determined by his unit of analysis-epistemes in The order of things and rationalities of government in the later work. This internal variation is one reason why a lighter reliance on the Foucault of the archaeology might have served Vigo de Lima better.

Nevertheless, the great merit of The order of things is that the reader is blocked from reading seventeenth-century writers as if they were early economists. This enduring anachronism in the history of economic thought is precluded by Foucault's assertion of a fundamental discontinuity, such that political economy is only possible once we enter the modern episteme around the turn of the nineteenth century. Foucault has certainly over-egged his pudding, and perpetuated the idea that mercantilism is a coherent unity, but the lesson regarding when we 
can start to speak sensibly of political economy is a valuable one, most powerfully made by Keith Tribe (1978), who drew a little inspiration from The order of things.

Returning to the marketing perspective, the difficulty arising from an emphasis on exegesis over new history is obvious. The economist is asked to subscribe to the existence of epistemes as underlying epistemological unities that govern what can be thought in particular fields, for example: "[m]ercantilism was determined by this context of the classical episteme" (p. 210). This is a major metaphysical commitment for anyone, but it is even more daunting in view of the fact that Foucault backed away from it himself soon after publication, although Vigo de Lima finds the episteme enduring in Foucault's work (p. 237). The economist is therefore asked not to read the authors of the canon in the more familiar ways-for theoretical concepts, in view of the intellectual or social context, through biography, and so on-as this would be to stay at the surface level of knowledge and not penetrate to the archaeological depths. The economist who would embrace all this is Vigo de Lima's boutique market.

An alternative pitch would have involved exploring some of Foucault's insights in relation to contemporary economics, thereby demonstrating their certain capacity to stimulate new research. As an example, Vigo de Lima helpfully draws out the idea that analyses of money and language were highly analogical in the classical period (roughly, 1650-1750). In particular, in classical thought language/money was treated as representing objects/wealth transparently, while in modern thought language is no longer seen to name things without difficulty, but is instead recognized as having a history and autonomy of its own. Foucault's tantalizing claim is that since language is still the medium for scientific knowledge this non-transparency is a problem, and one that has been addressed in two different ways. One was formalisation, as in the positivist's effort to forge a value free language, or Bertrand Russell's attempts to create a symbolic logic. The other was the turn to interpretation, the terrain occupied by Freud, for example. Note that Foucault has little to say about the language/money analogy in the modern period, but a quick look at macroeconomic theory might join up the dots. For in general, money is treated as either a more or less accurate reflection of a real economy of goods and services (Friedman); or, in contrast, as a thing in its own right, that should not be reduced to a mere reflection of some other process (Keynes, Marx). The majority of 
the mainstream analysis of inflation specifies money in this first sense, and hence much of economics is concerned with the problem of 'money illusion', while general equilibrium models introduce money into barter models with minimal changes in results. If, however, we look across at the new economic sociology, then we find that money is to be interpreted for its social meaning, using the suite of sociology's techniques (see, for example, Smelser and Swedberg 2005). Thus, one might claim that the analysis of money again reproduces the intellectual tactics brought to the study of language.

Broad schemas of this type are what Foucault furnishes in The order of things, but they need to be put to work, revised, and developed. Vigo de Lima hands this task on to others, hence she writes that Foucault "offered a novel perspective, together with a range of inspiring notions [...] which cannot be ignored by anyone intending to study the methodology and historiography of economics" (p. 243). This book is useful as a guide to Foucault's archaeology of political economy, which is what the author set out to provide. But my sense is that this conceals the simplicity of Foucault's overall method: first, suspend commitment to the self-evidence of economic thought and practice in order to narrate the emergence of economics in historical terms; second, do this by reading canonical texts for what they talk about and how, with an eye for shifts in the objects of discourse and the concepts that make these objects intelligible. The key idea is to substitute looking for the origins or immanence of economic thought and instead open up the possibility that there may have been something entirely different before political economy that we nevertheless persist in seeing as early economics. We may not need the theoretical machinery of archaeology to pursue this task, but only a humbler form of historiography.

\section{REFERENCES}

Burchell, Graham, Colin Gordon, and Peter Miller (eds.). 1991. The Foucault effect: studies in governmentality. London: Harvester Wheatsheaf.

Dean, Mitchell. 1999. Governmentality: power and rule in modern society. London: Sage. Foucault, Michel. 2007. Security, territory, population: lectures at the College de France, 1977-1978, ed. Michel Senellart, trans. Graham Burchell. Basingstoke: Palgrave Macmillan.

Foucault, Michel. 2008. The birth of biopolitics: lectures at the Collège de France, 19781979, ed. Michel Senellart, trans. Graham Burchell. Basingstoke: Palgrave Macmillan.

Rose, Nikolas. 1999. Powers of freedom: reframing political thought. Cambridge (UK): Cambridge University Press. 
Smelser, Neil, and Swedberg, Richard (eds.). 2005. The handbook of economic sociology. Princeton (NJ): Princeton University Press.

Tribe, Keith. 1978. Land, labour, and economic discourse. London: Routledge and Kegan Paul.

Ryan Walter teaches history of political and economic thought at the Australian National University. His monograph A critical history of the economy was published by Routledge in 2011.

Contact e-mail: <Ryan.Walter@anu.edu.au> 